\title{
Voltage-Dependent P/Q-Type Calcium Channels at the Frog Neuromuscular Junction
}

\author{
L. F. NURULLIN ${ }^{1}$, A. R. MUKHITOV ${ }^{1}$, A. N. TSENTSEVYTSKY ${ }^{1}$, N. V. PETROVA ${ }^{1}$, \\ D. V. SAMIGULLIN ${ }^{1}$, A. I. MALOMOUZH ${ }^{1}$, E. A. BUKHARAEVA ${ }^{1,2}$, F. VYSKOČIL $^{3,4}$, \\ E. E. NIKOLSKY ${ }^{1,2}$
}

\author{
${ }^{1}$ Kazan Institute of Biochemistry and Biophysics, Russian Academy of Sciences, Kazan, Russia, \\ ${ }^{2}$ Kazan Medical University, Kazan, Russia, ${ }^{3}$ Department of Animal Physiology, Faculty of \\ Sciences, Charles University, Prague, Czech Republic, ${ }^{4}$ Institute of Physiology, Academy of \\ Sciences of the Czech Republic, Prague, Czech Republic
}

Received April 28, 2011

Accepted June 14, 2011

On-line August 1, 2011

\section{Summary}

It is well known that antagonists of $\mathrm{N}$-type voltage-gated calcium channels inhibit the evoked quantal release of acetylcholine in amphibian neuromuscular synapses. This, however, does not exclude the functional expression of other types of voltage-gated calcium channels in these nerve terminals. Using immunocytochemistry, we detected the expression of the $\alpha 1 \mathrm{~A}$ subunit of P/Q-type calcium channels (that is otherwise typical of mammalian motor nerve endings) in the frog neuromuscular junction. In addition, we demonstrated that the P/Q-type channel blocker $\omega$-agatoxin IVA $(20 \mathrm{nM})$ reduced the action potentialinduced calcium transient and significantly decreased both spontaneous and evoked mediator release. Our data indicates the functional expression of P/Q-type calcium channels in the frog motor nerve ending which participate in acetylcholine release.

\section{Key words}

Neuromuscular transmission - Motor nerve terminal • Acetylcholine release $\bullet \mathrm{N}$ - and $\mathrm{P} / \mathrm{Q}$-type calcium channels

\section{Corresponding author}

František Vyskočil, Institute of Physiology, Vídeňská 1083, Prague - 4, Czech Republic. E-mail: vyskocil@biomed.cas.cz and

Leniz F. Nurullin, Kazan Institute of Biochemistry and Biophysics, Russian Academy of Sciences, P.O. box 30, 420111 Kazan, Russia. E-mail: leniz2001@mail.ru

\section{Introduction}

Calcium entry into the presynaptic nerve terminal through voltage-gated $\mathrm{Ca}^{2+}$ channels is fundamental for the initiation of quantal neurotransmitter release. The main role in triggering the exocytosis of synaptic vesicles in the amphibian neuromuscular junction is attributed to N-type $\mathrm{Ca}^{2+}$ channels (Hattori and Maehashi 1991, Robitaille et al. 1993, Katz et al. 1995, Macleod et al. 1999, Thaler et al. 2001). However, evidence has accumulated indicating the primary participation of L-type calcium channels in neurotransmission (Fu and Huang 1994, Arenson and Gill 1996, Arenson and Evans 2001, Thaler et al. 2001). The $\mathrm{P} / \mathrm{Q}$ - type was found almost exclusively at human motor nerve endings (Protti et al. 1996, Day et al. 1997), although perhaps there are also very low numbers of N-type channels (Day et al. 1997). In rodents, the population of $\mathrm{Ca}^{2+}$ channels is more diverse. In addition to a significant number of $\mathrm{P} / \mathrm{Q}$ channels (Uchitel et al. 1992, Protti and Uchitel 1993, Sugiura et al. 1995, Day et al. 1997), N-type channels are also expressed (Hamilton and Smith 1992, Mynlieff and Beam 1994, Westenbroek et al. 1998). Moreover, L-type channels (Anderson and Harvey 1987, Hong et al. 1995) were identified in rodents which are apparently not directly involved in the process of vesicle exocytosis, but may play a role in remodeling the synapse (Oliveira et al. 2004). In amphibian nerve terminals, N-channels are considered to be a major type 
in the triggering of exocytosis (Hattori and Maehashi 1991, Robitaille et al. 1993, Katz et al. 1995, Macleod et al. 1999, Thaler and Brehm 2001) together with L-type (Fu and Huang 1994, Arenson and Gill 1996, Arenson and Evans 2001, Thaler and Brehm 2001). The presence of P/Q-type calcium channels at the amphibian presynaptic membrane is debatable, because using pharmacological tools produced ambiguous results (Katz et al. 1995).

In this study we addressed the following questions: (i) is there molecular/functional expression of $\mathrm{P} / \mathrm{Q}$-type calcium channels in the frog neuromuscular junction, (ii) where these channels are located, and (iii) what the role of $\mathrm{P} / \mathrm{Q}$-type $\mathrm{Ca}^{2+}$ channels is in neuromuscular transmission. Using an immunofluorescent technique, the presence of $\alpha 1 \mathrm{~A}$ pore-forming subunits of $\mathrm{P} / \mathrm{Q}$-type calcium channels (Hofmann et al. 1994) was determined in the nerve terminal and the distribution of these subunits across the endplate was visualized. The functional relevance of these channels was confirmed by analyzing the quantal release of neurotransmitter and calcium transients in the nerve terminal in the control and in the presence of specific blockers.

\section{Materials and Methods}

\section{Animals and preparations}

Experiments were carried out on isolated preparations of cutaneous pectoris muscle from the frog Rana ridibunda and on diaphragms excised from adult male Wistar rats with body masses of 250-300 g. Animals were anesthetized with ether before being stunned and pithed in accordance with the European Communities Council Directive (24th November 1986; 86/609/EEC); the protocol of the experiments was approved by the Animal Care and Use Committee of Kazan State Medical University and the Czech Academy of Sciences.

\section{Immunocytochemistry}

Samples of cutaneous pectoris muscle were fixed for $30 \mathrm{~min}$ with $3 \% \mathrm{p}$-formaldehyde solution prepared in phosphate buffer saline (PBS, Sigma, St Louis, MO, USA), washed 3 times for $30 \mathrm{~min}$ in PBS. Muscles were sequentially incubated: (a) for $30 \mathrm{~min}$ with $0.3 \%$ Triton X-100 (Sigma) in PBS, (b) for 15 min with $5 \%$ normal goat serum (Sigma), $1 \%$ bovine serum albumin (BSA, Sigma) and $0.01 \%$ Triton X-100 in PBS and (c) for 15 min with $1 \%$ BSA and $0.01 \%$ Triton
$\mathrm{X}-100$ in PBS (solution A) (Malomouzh et al. 2011).

The muscles were subsequently incubated for $15 \mathrm{~h}$ at $4{ }^{\circ} \mathrm{C}$ with rabbit polyclonal antibodies against the $\alpha 1 \mathrm{~A}$ subunit of $\mathrm{P} / \mathrm{Q}$-type $\mathrm{Ca}^{2+}$ channels (1:100; Sigma) or to the $\alpha 1 \mathrm{~B}$ subunit of N-type in solution A (1:200; Sigma). After this incubation, muscles were rinsed in solution A 3 times for $30 \mathrm{~min}$ and incubated for $1 \mathrm{~h}$ at room temperature with fluorescein isothiocynate (FITC)conjugated goat anti-rabbit antibodies (Sigma) in solution A (1:200).

Muscle endplate zones were visualized by labeling postsynaptic nicotinic acetylcholine receptors with fluorescent $\alpha$-bungarotoxin. This was done by incubating for $30 \mathrm{~min}$ in darkness at room temperature with $20 \mu \mathrm{g} / \mathrm{ml}$ tetra-metyl-rhodamine isothiocyanateconjugated (TRITC)- $\alpha$-bungarotoxin (Sigma) (Anderson and Cohen 1974, Krause and Wernig 1985).

The final step in all of these procedures was to mount the preparations in a special solution of anti-fading reagent (Sigma) on glass slides for microscopic observation.

\section{Western blot analysis}

Samples of frog cutaneous pectoris muscles and rat diaphragm were homogenized in HEPES buffer (Sigma; $5 \mathrm{mM}$ HEPES and 0.32 sucrose, $\mathrm{pH}$ 7.4) with the following protease inhibitors: $1 \mathrm{mM}$ phenylmetylsulfonil fluoride (PMSF, Sigma), $1 \mathrm{mM}$ ethylene glycol tetraacetic acid (EGTA, Sigma) and $1 \mathrm{mM}$ theophyllin (Sigma). The probe was centrifuged at $800 \mathrm{~g}$ for $10 \mathrm{~min}$ at $4{ }^{\circ} \mathrm{C}$ to remove the nuclei. The supernatants were centrifuged at $10000 \mathrm{~g}$ for $30 \mathrm{~min}$ at $4{ }^{\circ} \mathrm{C}$. The pellet was collected and suspended in PBS, containing $2 \%$ sodium dodecyl sulfate (Sigma), $2 \%$ Triton-X100, CHAPS $2 \%$, $1 \mathrm{mM}$ PMSF, $1 \mathrm{mM}$ EGTA, $1 \mathrm{mM}$ theophyllin. The probe was centrifuged at $10000 \mathrm{~g}$ for $30 \mathrm{~min}$ at $4{ }^{\circ} \mathrm{C}$. The supernatant was collected and run on $10 \%$ polyacrylamide gels with $4 \%$ stacking gel and than transferred onto a PVDF membrane (Amersham Biosciences, Buckinghamshire, UK). The membranes were blocked overnight at $4{ }^{\circ} \mathrm{C}$ in $1 \%$ BSA in Trisbuffered saline with $0.1 \%$ Tween-20 (Sigma). After blocking, the membranes were incubated with rabbit antibodies against the $\alpha 1 \mathrm{~A}$ subunit of $\mathrm{P} / \mathrm{Q}$-type $\mathrm{Ca}^{2+}$ channels (1:1000; Sigma) or to the $\alpha 1 \mathrm{~B}$ subunit of N-type (1:1000; Sigma) for 1 hour and then with horseradish peroxidase-conjugated anti-rabbit IgG (1:2500; Bio-Rad Laboratories, Hercules, CA, USA) for 1 hour. The specificity of the secondary antibodies was confirmed by 
omitting the primary antibody (images not shown). Immunoreactive proteins on the membranes were visualized using ECL-reagents (Amersham Biosciences).

\section{Microscopy and image processing}

For microscopic observation and image acquisition, we used a Leica TCS SP5 confocal microscope (Leica, Germany) equipped with a set of lasers with a wavelength range from ultra-violet to red. Observations were performed using a $63 \mathrm{x}$ oil immersion lens (1.40 NA, Leica, Germany). Fluorochromes were excited with an argon laser for FITC at $488 \mathrm{~nm}$ and a helium-neon laser for TRITC at $543 \mathrm{~nm}$.

For estimating the density distributions of calcium channels, the images were transformed to 12-bit grayscale format and processed using ImageJ 1.44 software (NIH, USA). Regions of interest of the same size were chosen in the distal and proximal parts of the nerve terminal and the integrated density of fluorescence was measured. Estimations were performed for 20-25 nerve terminals for each type of channel. The data was processed statistically using Excel (Microsoft Corp., USA).

\section{Recording of calcium transient in nerve terminal}

In order to characterize the functional activity of P/Q-type calcium channels and to estimate their contribution to the calcium transient during an action potential we used Oregon Green 488 BAPTA-1, hexapotassium salt ( $50 \mathrm{mmol} / \mathrm{l}$; Invitrogen, Carlsbad, CA, USA)-based calcium fluorimetry. The dye was loaded through the nerve stump as described by Peng and Zucker (1993) and $\mathrm{Wu}$ and Betz (1996). After the loading procedure, virtually all nerve terminals in the proximal part of the main nerve bundle were fluorescent and could be used for the imaging procedure. Concentrations of the dye in the loaded nerve were estimated to range from 40 to $150 \mu \mathrm{M}$ (Suzuki et al. 2000). In our experiments, the loading and incubation procedures had no detectable effect on EPC amplitude and MEPC frequency, in agreement with previous data (Wu and Betz 1996). The nerve was stimulated via suction electrode with suprathreshold rectangular stimuli with a duration of $0.2 \mathrm{~ms}$ and frequency $0.5 \mathrm{~Hz}$.

The photodiode (S1087, Hamamatsu Photonics, Japan) was connected to the output of the viewfinder to record fluorescence transients in an upright microscope (Olympus BX51WI) with a $\times 40$ water immersion lens (0.80 NA, Olympus, Japan) and a filter set consisting of a
505 dcxt dichroic mirror and an E5201p emission filter (Chroma Technology Corp., USA) were used to detect fluorescent signals. A viewfinder optical system (Till Photonics, Germany) was used to choose the recording range of the calcium signal. A Polychrome V monochromator (Till Photonics, Germany) was used with the excitation amplitude set to $488 \mathrm{~nm}$. To reduce dye bleaching, the chosen area of neuromuscular junction was illuminated for the $400 \mathrm{~ms}$ required for recording the calcium signal. To reduce background fluorescence, the recording zone was illuminated only through the iris diaphragm.

Approximately 60 signals under control conditions and after $\omega$-agatoxin IVA (Sigma) treatment (a blocker of $\mathrm{P} / \mathrm{Q}$-type $\mathrm{Ca}^{2+}$ channels) were recorded in each experiment. This recording procedure did not cause significant dye bleaching. Specifically, there was no detectable decrease in the amplitude of the calcium transient in test experiments with dye bleaching (data not shown).

To optimize the signal to noise ratio, the recordings were performed using the whole nerve terminal (approx $100 \mu \mathrm{m}$ long). Signals from the photodiode were digitized using a Digidata 1200B analog/digital converter (Axon Instruments, USA). Calcium signal detection and synchronization of illumination and stimulation were performed using WinWcp software (Stanford University, USA). Fluorescence changes are represented as $\Delta \mathrm{F}$ i.e. relative change in fluorescent intensity. Relative changes in the calcium transient were compared to eliminate the possible effects of actual dye concentrations in the individual nerve terminals.

\section{Electrophysiology}

An isolated neuromuscular preparation of $\mathrm{m}$. cutaneous pectoris was placed in a 3-ml translucent chamber and superfused with the following solution (mM): $\mathrm{NaCl}, 113.0 ; \mathrm{KCl}, 2.5 ; \mathrm{NaHCO}_{3}, 3.0 ; \mathrm{MgCl}_{2}, 4.0$; $\mathrm{CaCl}_{2}, 0.3$ (pH 7.2-7.3; temperature, $20.0 \pm 0.3{ }^{\circ} \mathrm{C}$ ). The solution flowed through the chamber at the rate of $5 \mathrm{ml} / \mathrm{min}$.

The nerve ending currents and endplate currents were recorded extracellularly with microelectrodes (filled with Ringer solution, with a resistance of 2.0-4.0 M $\Omega$ ) from the proximal synaptic area $(5-10 \mu \mathrm{m}$ away from the end of the axon myelin sheath).

The intensity of spontaneous quantal release of acetylcholine was estimated using the average frequency 
of miniature endplate currents (mEPCs), which in each experiment was estimated after recording over 120 signals under the control conditions and after the application of the $\mathrm{P} / \mathrm{Q}$-type $\mathrm{Ca}^{2+}$ channel blocker agatoxin IVA.

The quantal content of endplate currents (EPCs) under conditions of low calcium concentration was estimated using the "method of failures" (Del Castillo and Katz 1954, Martin 1955). The motor nerve was stimulated with rectangular impulses $(0.1 \mathrm{~ms}$ duration, supramaximal amplitude and $0.5 \mathrm{imp} / \mathrm{s}$ frequency). We recorded 250-400 uniquantal postsynaptic responses and nerve ending currents and digitized them with a sampling frequency of $5 \mu \mathrm{s}$.

Each of the experimental series included the recordings from 5-8 endplates $(n)$.

The recorded mEPCs and EPCs were digitized with an analog/digital 9 bit-converter, filtered between $0.03 \mathrm{~Hz}$ to $10 \mathrm{~Hz}$, fed into a computer, and processed with our software package.

\section{Statistics}

Measurements are expressed as mean \pm SEM ( $n=$ number of experiments), with statistical significance assessed by Student's paired t test. A $p$ value of $<0.05$ was accepted as indicative of statistically significant differences between groups.

\section{Results}

Detection of P/Q-type $\mathrm{Ca}^{2+}$ channels at frog neuromuscular junction

For visualizing P/Q-type $\mathrm{Ca}^{2+}$ channels in the endplate area, we used antibodies against the $\alpha 1 \mathrm{~A}$ subunit which contains the voltage sensor, gating apparatus and forms an ion-permeation pore. Acetylcholine receptor labeling with TRITC-conjugated $\alpha$-bungarotoxin was used as a marker of the endplate area.

The interaction of TRITC- $\alpha$-bungarotoxin with endplate acetylcholine receptors revealed specific labeling in the form of bands with a high fluorescence density (Fig. 1). Immunocytochemical reaction of antibodies against the $\alpha 1 \mathrm{~A}$ subunit of P/Q-type $\mathrm{Ca}^{2+}$ channels produced staining in the form of small dots distributed irregularly throughout the length of the nerve terminal (Fig. 1). Double labeling of acetylcholine receptors and the $\alpha 1 \mathrm{~A}$ subunit showed that P/Q-type $\mathrm{Ca}^{2+}$ channels were located in the area of the motor nerve terminal. It is important to note that $\mathrm{P} / \mathrm{Q}$-type $\mathrm{Ca}^{2+}$

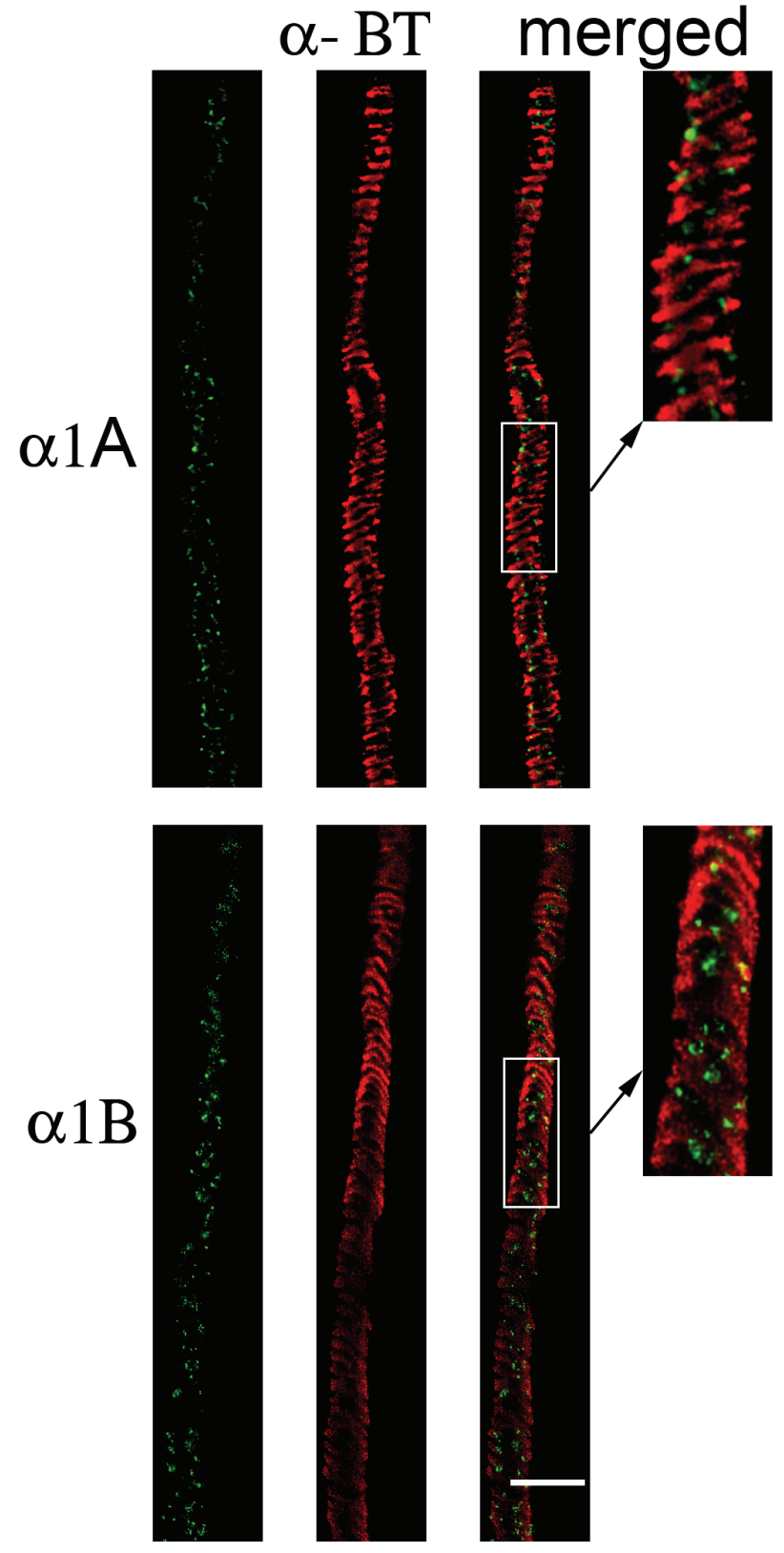

Fig. 1. Immunocytochemical labeling of $a 1 A$ subunit of $P / Q$-type (top) and a1B subunit of $\mathrm{N}$-type (bottom) $\mathrm{Ca}^{2+}$ channels (green) at frog neuromuscular junction. a-BT - Staining of postsynaptic acetylcholine receptors with TRITC-a-bungarotoxin (red). Merged images illustrating the relative distribution of $\mathrm{P} / \mathrm{Q}$ and $\mathrm{N}$-type $\mathrm{Ca}^{2+}$ channels and acetylcholine receptors. Enlargement of part of the neuromuscular junction (right panels) demonstrates that the majority of $\mathrm{Ca}^{2+}$ channels are located between the bands of acetylcholine receptors. Scale bar, $10 \mu \mathrm{m}$.

channel spots were mostly located between the bands of postsynaptic acetylcholine receptors (Fig. 1).

Localization of $\mathrm{N}$-type $\mathrm{Ca}^{2+}$ channels at neuromuscular junction

Labeling both the endplate area for acetylcholine receptors and the $\alpha 1 \mathrm{~B}$ subunit showed that $\mathrm{N}$-type $\mathrm{Ca}^{2+}$ 
channels, like P/Q-type $\mathrm{Ca}^{2+}$ channels, are clasterized and generally located between the bands of postsynaptic acetylcholine receptors (Fig. 1). An analysis of fluorescence density distribution for P/Q- and N-type $\mathrm{Ca}^{2+}$ channels in various parts of the nerve terminal did not reveal a significant difference between the proximal and distal parts of the nerve ending.

The fluorescence density distribution of the antibodies against the $\alpha 1 \mathrm{~A}$ subunit and $\alpha 1 \mathrm{~B}$ subunit in the distal region of the synaptic contact was $104 \pm 14 \%$ $(n=20, p>0.05)$ for P/Q- and $111 \pm 12 \% \quad(n=25, p>0.05)$ for $\mathrm{N}$-type $\mathrm{Ca}^{2+}$ channels relative to the proximal part. Thus, both types of calcium channels are distributed practically uniformly along the extended frog motor nerve terminal.

Verification of antibody specificity for $P / Q$ - and $N$-types $\mathrm{Ca}^{2+}$ channels in frog

Because we used antibodies intended for detecting P/Q- and N-types $\mathrm{Ca}^{2+}$-channels (typical of the rat motor nerve ending (Westenbroek et al. 1998)) in mammals it was necessary to verify the identity of the proteins (from rat and frog) which binded with the antibodies used. This was done by isolating, the samples of muscle regions enriched with nerve endings from frog $\mathrm{m}$. cutaneous pectoris and rat diaphragm and analyzing by Western blot.

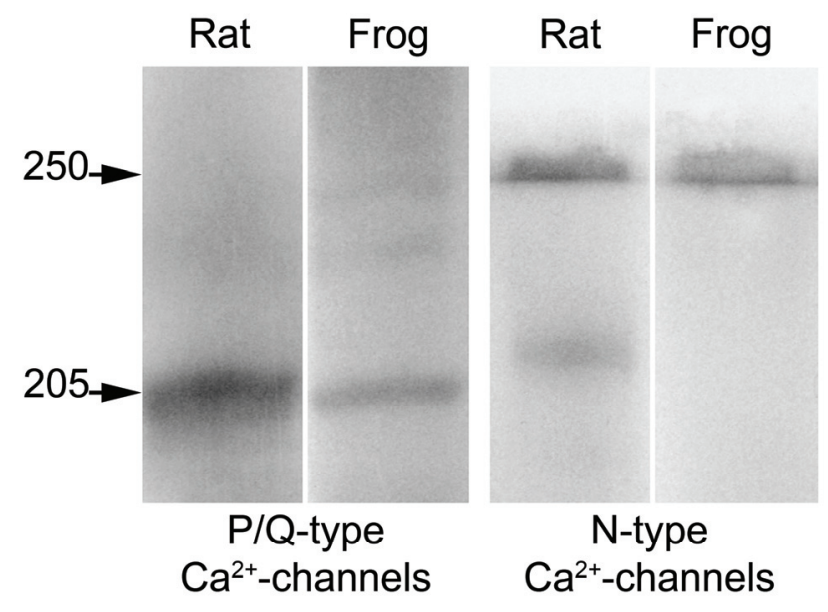

Fig. 2. Western blots of immunoprecipitated a1A subunit (P/Qtype) and a1B subunit (N-type) of $\mathrm{Ca}^{2+}$ channels from rat and frog neuromuscular preparations. Molecular weight markers in kilodaltons $(\mathrm{kDa})$ are indicated on the left.

Western blots (Fig. 2) probed with antibodies against both $\mathrm{Ca}^{2+}$ channels, revealed that extracts prepared from frog neuromuscular preparations exhibited bands of immunoreactivity with the same molecular mass as the $\mathrm{P} / \mathrm{Q}$ - and $\mathrm{N}$-types bands observed in rat diaphragm extracts (about 210 and $250 \mathrm{kDa}$, respectively). These results suggest that proteins recognized by rabbit polyclonal antibodies against the $\alpha 1 \mathrm{~A}$ and $\alpha 1 \mathrm{~B}$ subunit of $\mathrm{Ca}^{2+}$ channels in frogs have identical molecular weight and antigen structure to the subunits of rat $\mathrm{Ca}^{2+}$ channels.

\section{Functional activity of $\mathrm{P} / Q$-type $\mathrm{Ca}^{2+}$ channels}

The detection of a single channel-forming subunit does not enable us to identify the type of channel formed by this polypeptide. To obtain direct evidence that $\mathrm{P} / \mathrm{Q}$-type $\mathrm{Ca}^{2+}$ channels are actually functional and located at the nerve terminal, we recorded the calcium transients in the nerve ending induced by action potential in the control and in the presence of a P/Q-type calcium channel blocker.

After loading the calcium-sensitive dye through the nerve stump, the resting fluorescence was observed in the terminal branching area. The intensity of this fluorescence transiently increased following motor nerve stimulation, reflecting calcium level elevation initiated by calcium entering through voltage-gated $\mathrm{Ca}^{2+}$ channels in the nerve terminal (Vyshedskiy and Lin 2000). Local application of $20 \mathrm{nM}$ of $\omega$-agatoxin IVA (a selective blocker of P/Q-type $\mathrm{Ca}^{2+}$ channels) (Olivera et al. 1994, Meir et al. 1999) significantly reduced the amplitude of the calcium transient evoked by a single nerve stimulation by $19 \pm 2.8 \%(n=6, p<0.05$, Fig. 3$)$.

Thus, it was proved that voltage-gated P/Q-type $\mathrm{Ca}^{2+}$ channels make a contribution to the change in the calcium transient in the nerve terminal during an action potential. These results, together with immunocytochemical evidence of the similarity in the pattern of distribution of these channels and N-type channels along the nerve terminal, enabled us to suggest the presynaptic localization of P/Q-type calcium channels and their participation in the processes of quantal release.

\section{Role of $\mathrm{P} / Q$-type $\mathrm{Ca}^{2+}$ channels in neurotransmitter release}

To study the role of $\mathrm{P} / \mathrm{Q}$-type $\mathrm{Ca}^{2+}$ channels in neurotransmission, we measured the parameters of spontaneous (mEPCs frequency) and evoked (quantal content of EPCs) release of the mediator before and after $\omega$-agatoxin IVA application.

The mean frequency of mEPCs in the control was $0.28 \pm 0.07 \mathrm{~s}^{-1}(n=12)$. After one hour of incubation with $\omega$-agatoxin IVA $(20 \mathrm{nM})$ the frequency of 
A

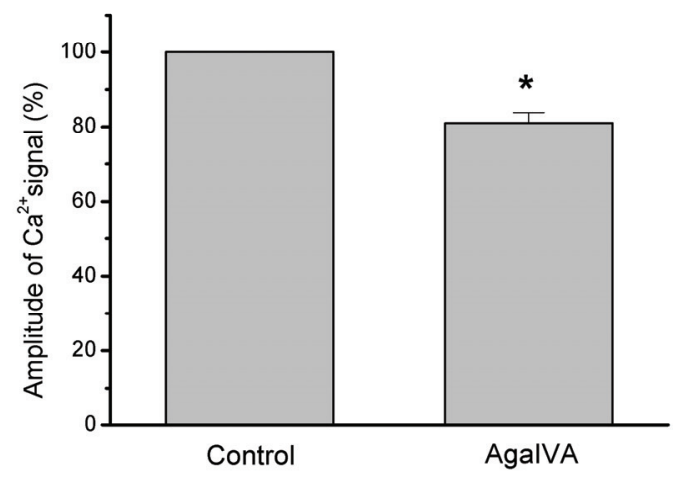

B

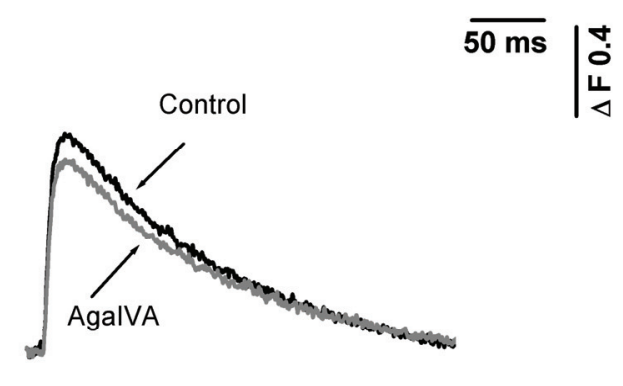

Fig. 3. A: Effect of $\omega$-agatoxin IVA $(20 \mathrm{nM})$ on amplitude of action potential-induced calcium transients in frog motor nerve terminal. B: superposition of calcium transients detected in nerve ending before and after $\omega$-agatoxin IVA application in single experiment, each trace is the mean of 60 signals.

A

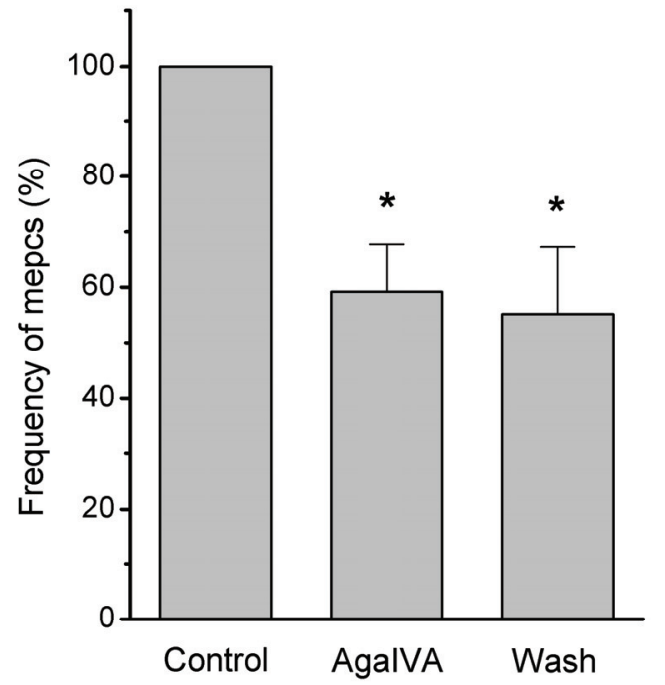

B

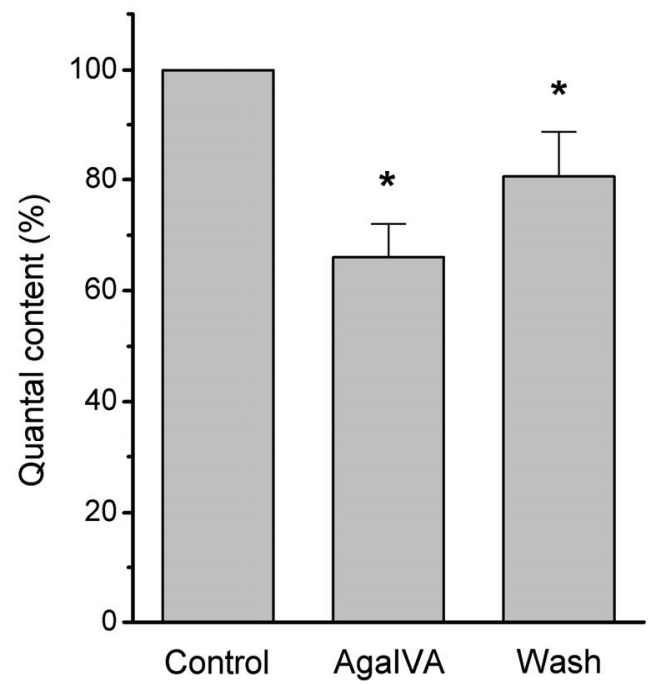

Fig. 4. Effects of $\omega$-agatoxin IVA on spontaneous and evoked quantal release of mediator at frog neuromuscular junction. Decrease in mEPC frequency (panel A) and quantal content (panel B) expressed as a percentage of control values, set as $100 \%$. Asterisks (*) indicate a statistically significant difference $(p<0.05)$ from the control value.

spontaneous signals decreased by $40.9 \pm 8.6 \%$ compared to the control values $(n=7, p<0.05$, Fig. $4 \mathrm{~A})$. The mean quantal content of the evoked currents under control conditions was $0.38 \pm 0.07 \quad(n=15)$. The addition of $\omega$-agatoxin IVA decreased the quantal content by $34 \pm 6 \%$ $(n=7, p<0.05$, Fig. 4B).

\section{Discussion}

Direct $\mathrm{Ca}^{2+}$ measurements from frog nerve terminals demonstrated the contribution of $\mathrm{P} / \mathrm{Q}$ channels to the generation of action-potential induced $\left[\mathrm{Ca}^{2+}\right]_{\mathrm{i}}$ transients. Furthermore, we demonstrated the presence of P/Q-type channels imunocytochemically and showed that their blocker, $\omega$-agatoxin IVA, decreases both the quantal content of evoked responses and the intensity of spontaneous quantal release.

The importance of voltage-dependent calcium channels in neurotransmitter release from presynaptic terminals has long been appreciated (Katz and Miledi 1967). $\mathrm{Ca}^{2+}$ influx through these channels increases intracellular $\mathrm{Ca}^{2+}$ concentration in a spatially restricted 'microdomain' that triggers synaptic vesicle fusion from the local active zone (Yoshikami et al. 1989). 
Determining which of these channels are involved in neurotransmitter release is of fundamental importance for understanding the basic mechanisms of exocytosis and synaptic transmission. Voltage-gated $\mathrm{Ca}^{2+}$ channels have been shown to be located at the active zones of neuromuscular junctions, where they play a critical role in regulating vesicle fusion (Cohen et al. 1991, Robitaille et al. 1993). It is generally believed that with several types of voltage-gated $\mathrm{Ca}^{2+}$ channels (L-, N-, P/Q-, T- and $\mathrm{R}$-type), release at peripheral neuromuscular junctions is mediated by a single type of calcium channel. In adult frog neuromuscular junctions, N-type channels are thought to mediate transmitter release (Kerr and Yoshikami 1984, Robitaille et al. 1993), whereas the $\mathrm{P} / \mathrm{Q}$-type channels serve this function at mammalian neuromuscular junctions (Protti et al. 1996). At the same time, several lines of evidence indicate the possible role of other $\mathrm{Ca}^{2+}$ channels in the regulation of neurotransmitter release in the neuromuscular junction. First, the funnel-web spider toxin (FTX), a specific P/Q channels blocker, was shown to decrease the amount of released neurotransmitter in frog synapses (Katz et al. 1995). Second, nitrendipine and nimodipine, L-type $\mathrm{Ca}^{2+}$ channels blockers, were demonstrated to reduce calcium current in the varicosities of developing Xenopus synapses (Thaler et al. 2001) whereas the L-type $\mathrm{Ca}^{2+}$ channel activator BAYK 8644 increased the quantal content in the neuromuscular junction of frog sartorius muscle (Arenson and Gill 1996). Atchison (Atchison 1989) reported that although L-type $\mathrm{Ca}^{2+}$ channels may be present at adult neuromuscular junctions in both rat and mouse, these channels play no role in transmitter release under physiological conditions. In the neuromuscular junction of adult frogs, nimodipine (an L-type $\mathrm{Ca}^{2+}$ channel blocker) had no effect on either spontaneous or evoked transmitter release. However, application of the phosphatase inhibitor okadaic acid increased the frequency of spontaneous release, and this enhancement was blocked by nimodipine (Atchison 1989). These results suggest that a population of silent L-type $\mathrm{Ca}^{2+}$ channels in the presynaptic terminals may be recruited by phosphorylation.

Identification of the calcium channel types underlying synaptic transmission has been based primarily on pharmacological profiles of the inhibition of either postsynaptic responses or directly measured transmitter release. Our findings indicate that distinct calcium channel subtypes other than N-type and L-type $\mathrm{Ca}^{2+}$ channels also contribute to acetylcholine release at adult frog neuromuscular junctions.

Using immunocytochemical methods combined with confocal microscopy revealed the presence of the basic channel-forming subunit of P/Q-type $\mathrm{Ca}^{2+}$ channels $(\alpha 1 \mathrm{~A})$ in the nerve terminal. Though polyclonal antibodies do not allow the exact quantity of labeled proteins to be determined, a comparison of the images obtained after using antibodies against $\alpha 1 \mathrm{~A}$ and $\alpha 1 \mathrm{~B}$ enabled us to conclude that, despite $\mathrm{N}$-type $\mathrm{Ca}^{2+}$ channels being predominant, $\mathrm{P} / \mathrm{Q}$-type $\mathrm{Ca}^{2+}$ channels are also present in the frog neuromuscular junction. We demonstrated that both types of calcium channels are distributed along the extended frog motor nerve terminals relatively uniformly.

One can only speculate why the presence of $\mathrm{P} / \mathrm{Q}$-type $\mathrm{Ca}^{2+}$ channels is so important for neuromuscular transmission and what the advantage of this channel is compared to other calcium channels. First of all, the stimulation-induced increases in cytosolic $\mathrm{Ca}^{2+}$ (which are mediated by $\mathrm{P} / \mathrm{Q}$-type channels) are highly temperature-dependent over the range $18-38{ }^{\circ} \mathrm{C}$ in mouse nerve terminals (David and Barrett, 2000). In contrast, the stimulation-induced increases in cytosolic $\mathrm{Ca}^{2+}$ measured in lizard nerve endings (which are mostly mediated by N-type channels) exhibited little or no temperature dependence between 18 and $38{ }^{\circ} \mathrm{C}$. The presence of $\mathrm{P} / \mathrm{Q}$ channels (conducting more calcium at low temperatures) in cold-blooded animals, along with the $\mathrm{N}$ type (whose activity does not depend on temperature) can be regarded as an adaptation of the neuromuscular transmission of these vertebrates to ambient temperature changes. But why are $\mathrm{P} / \mathrm{Q}$ channels preferred in mammals? Perhaps this is due to their behavior during activity. As stated by Ishikawa et al. (2005) for calyces of Held, the most prominent feature of $\mathrm{P} / \mathrm{Q}-$ type $\mathrm{Ca}^{2+}$ currents is their activity-dependent facilitation, which is absent in N-type $\mathrm{Ca}^{2+}$ currents. Postsynaptic excitatory potentials mediated by P/Q-type $\mathrm{Ca}^{2+}$ currents exhibit less depression during high-frequency stimulation compared with those mediated by $\mathrm{N}$-type $\mathrm{Ca}^{2+}$ currents. This suggests that the developmental switch of presynaptic $\mathrm{Ca}^{2+}$ channels from $\mathrm{N}$ - (dominant in amphibians and reptiles) to P/Q-type (dominant in mammals) may serve to increase synaptic efficacy at high frequencies of activity, ensuring highfidelity synaptic transmission. The co-existence of several types of $\mathrm{Ca}^{2+}$ channels in a nerve terminal may thus increase the reliability of synaptic transmission and enhance synaptic plasticity. 


\section{Conflict of Interest}

There is no conflict of interest.

\section{Acknowledgements}

The authors are grateful to Professor Alexej Verkhratsky (University of Manchester, School of Biological Sciences, UK) and Professor Lev Magazanik (Sechenov Institute of Evolutionary Physiology and Biochemistry RAS, Saint Petersburg, Russia) for reading the manuscript and for their helpful comments and discussion. The study was supported by grants from the RFBR (projects nos. 09-04-01-280, 10-04-00765) and programs of the President of the Russian Federation. F.V. was supported by IAA500110905, GAČR 202/09/0806 and AV0Z 0110509.

\begin{abstract}
Abbreviations
PBS - phosphate buffer saline, BSA - bovine serum albumin, FITC - fluorescein isothiocynate, TRITC tetra-metyl-rhodamine isothiocyanate, PMSF phenylmetylsulfonil fluoride, EGTA - ethylene glycol tetraacetic acid, Aga IVA - $\omega$-agatoxin IVA, mEPCs miniature endplate currents, EPCs - endplate currents
\end{abstract}

\section{References}

ANDERSON MJ, COHEN MW: Fluorescent staining of acetylcholine receptors in vertebrate skeletal muscle. $J$ Physiol 237: 385-400, 1974.

ANDERSON AJ, HARVEY AL: Omega-conotoxin does not block the verapamil-sensitive calcium channels at mouse motor nerve terminals. Neurosci Lett 82: 177-180, 1987.

ARENSON MS, EVANS SC: Activation of protein kinase C increases acetylcholine release from frog motor nerves by a direct action on L-type $\mathrm{Ca}(2+)$ channels and apparently not by depolarisation of the terminal. Neuroscience 104: 1157-1164, 2001.

ARENSON MS, GILL DS: Differential effects of an L-type $\mathrm{Ca}^{2+}$ channel antagonist on activity- and phosphorylationenhanced release of acetylcholine at the neuromuscular junction of the frog in vitro. Eur J Neurosci 8: 437445, 1996.

ATCHISON WD: Dihydropyridine-sensitive and -insensitive components of acetylcholine release from rat motor nerve terminals. J Pharmacol Exp Ther 251: 672-678, 1989.

COHEN MW, JONES OT, ANGELIDES KJ: Distribution of $\mathrm{Ca}^{2+}$ channels on frog motor nerve terminals revealed by fluorescent $\omega$-conotoxin. J Neurosci 11: 1032-1039, 1991.

DAVID G, BARRETT EF: Stimulation-evoked increases in cytosolic $\left[\mathrm{Ca}^{(2+)}\right]$ in mouse motor nerve terminals are limited by mitochondrial uptake and are temperature-dependent. $J$ Neurosci 20: 7290-7296, 2000.

DAY NC, WOOD SJ, INCE PG, VOLSEN SG, SMITH W, SLATER CR, SHAW PJ: Differential localization of voltage-dependent calcium channel alphal subunits at the human and rat neuromuscular junction. $J$ Neurosci 17: 6226-6235, 1997.

Del CASTILLO J, KATZ B: Statistical factors involved in neuromuscular facilitation and depression. $J$ Physiol 124: 574-585, 1954.

FU WM, HUANG FL: L-type $\mathrm{Ca}^{2+}$ channel is involved in the regulation of spontaneous transmitter release at developing neuromuscular synapses. Neuroscience 58: 131-140. 1994.

HAMILTON BR, SMITH DO: Calcium currents in rat motor nerve terminals. Brain Res 584: 123-131, 1992.

HATTORI T, MAEHASHI H: Activation of N-type calcium channels by stannous chloride at frog motor nerve terminals. Res Commun Chem Pathol Pharmacol 74: 125-128, 1991.

HOFMANN F, BIEL M, FLOCKERZI V: Molecular basis for $\mathrm{Ca}^{2+}$ channel diversity. Annu Rev Neurosci 17: 399-418, 1994.

HONG SJ, LEE SH, CHANG CC: Physiological and regenerative acetylcholine release from motor nerve: differential inhibitions by vesamicol and omega-agatoxin IVA. Neuroscience 67: 169-175, 1995.

ISHIKAWA T, KANEKO M, SHIN HS, TAKAHASHI T: Presynaptic N-type and P/Q-type $\mathrm{Ca}^{2+}$ channels mediating synaptic transmission at the calyx of Held of mice. J Physiol (Lond) 568:199-209, 2005.

KATZ B, MILEDI R: The timing of calcium action during neuromuscular transmission, J Physiol (Lond) 189: 535-544, 1967. 
KATZ E, FERRO PA, CHERKSEY BD, SUGIMORI M, LLINÁS R, UCHITEL OD: Effects of Ca ${ }^{2+}$ channel blockers on transmitter release and presynaptic currents at the frog neuromuscular junction. $J$ Physiol 486: 695-706, 1995.

KERR L, YOSHIKAMI D: A venom peptide with a novel presynaptic blocking action. Nature 308: 282-284, 1984.

KRAUSE M, WERNIG A: The distribution of acetylcholine receptors in the normal and denervated neuromuscular junction of the frog. J Neurocytol 14: 765-780, 1985.

MACLEOD GT, GAN J, BENNETT MR: Vesicle-associated proteins and quantal release at single active zones of amphibian (Bufo marinus) motor-nerve terminals. J Neurophysiol 82: 1133-1146, 1999.

MALOMOUZH AI, ARKHIPOVA SS. NIKOLSKY EE, VYSKOČIL F: Immunocytochemical demonstration of M1 muscarinic acetylcholine receptors at the presynaptic and postsynaptic membranes of rat. Physiol Res 60: 185 $188,2011$.

MARTIN AR: A further study of the statistical composition of the endplate potential. $J$ Physiol 130: 114-122, 1955.

MEIR A, GINSBURG S, BUTKEVICH A, KACHALSKY SG, KAISERMAN I, AHDUT R, DEMIRGOREN S, RAHAMIMOFF R: Ion channels in presynaptic nerve terminals and control of transmitter release. Physiol Rev 79: 1019-1088, 1999.

MYNLIEFF M, BEAM KG: Adenosine acting at an A1 receptor decreases N-type calcium current in mouse motoneurons. J Neurosci 14: 3628-3634, 1994.

OLIVEIRA L, TIMÓTEO MA, CORREIA-DE-SÁ P: Tetanic depression is overcome by tonic adenosine A(2A) receptor facilitation of L-type $\mathrm{Ca}^{2+}$ influx into rat motor nerve terminals. J Physiol 560: 157-168, 2004.

OLIVERA BM, MILJANICH GP, RAMACHANDRAN J, ADAMS ME: Calcium channel diversity and neurotransmitter release: the omega-conotoxins and omega-agatoxins. Annu Rev Biochem 63: 823-867, 1994.

PENG YY, ZUCKER RS: Release of LHRH is linearly related to the time integral of presynaptic $\mathrm{Ca}^{2+}$ elevation above a threshold level in bullfrog sympathetic ganglia. Neuron 10: 465-473, 1993.

PROTTI DA, REISIN R, MACKINLEY TA, UCHITEL OD: Calcium channel blockers and transmitter release at the normal human neuromuscular junction. Neurology 46: 1391-1396, 1996.

PROTTI DA, UCHITEL OD: Transmitter release and presynaptic $\mathrm{Ca}^{2+}$ currents blocked by the spider toxin omegaAga-IVA. Neuroreport 5: 333-336, 1993.

ROBITAILLE R, GARCIA ML, KACZOROWSKI GJ, CHARLTON MP: Functional colocalization of calcium and calcium-gated potassium channels in control of transmitter release. Neuron 11: 645-655, 1993.

SUGIURA Y, WOPPMANN A, MILJANICH GP, KO CP: A novel omega-conopeptide for the presynaptic localization of calcium channels at the mammalian neuromuscular junction. $J$ Neurocytol 24: 15-27, 1995.

SUZUKI S, OSANAI M, MURASE M, SUZUKI N, ITO K, SHIRASAKI T, NARITA K, OHNUMA K, KUBA K, KIJIMA H: $\mathrm{Ca}^{2+}$ dynamics at the frog motor nerve terminal. Pflugers Arch 440: 351-365. 2000.

THALER C, LI W, BREHM P: Calcium channel isoforms underlying synaptic transmission at embryonic Xenopus neuromuscular junctions. J Neurosci 21: 412-422, 2001.

UCHITEL OD, PROTTI DA, SANCHEZ V, CHERKSEY BD, SUGIMORI M, LLINÁS R: P-type voltage-dependent calcium channel mediates presynaptic calcium influx and transmitter release in mammalian synapses. Proc Natl Acad Sci U S A 89: 3330-3333, 1992.

VYSHEDSKIY A, LIN JW: Presynaptic $\mathrm{Ca}(2+)$ influx at the inhibitor of the crayfish neuromuscular junction: a photometric study at a high time resolution. J Neurophysiol 83: 552-562, 2000.

WESTENBROEK RE, HOSKINS L, CATTERALL WA: Localization of $\mathrm{Ca}^{2+}$ channel subtypes on rat spinal motor neurons, interneurons, and nerve terminals. J Neurosci 18: 6319-6330, 1998.

WU LG, BETZ WJ: Nerve activity but not intracellular calcium determines the time course of endocytosis at the frog neuromuscular junction. Neuron 17: 769-779, 1996.

YOSHIKAMI D, BALGABALDO Z, OLIVERA BM: The inhibitory effects of omega-conotoxins on Ca channels and synapses. Ann NY Acad Sci 560: 230-248, 1989. 